\title{
Analysis on Blood Transfusion Service System According to GMP (A Case Study in Blood Transfusion Unit of Indonesian Red Cross (UTD PMI) of PM)
}

\section{A. Emy Purnama*}

*Correspondent Author: a.emypurnama@yahoo.com

*Blood Transfusion Unit of Indonesian Red Cross, Polewali Mandar, West Sulawesi, Polewali Mandar Hospital, Indonesia

\begin{tabular}{l}
\hline I N D E X I N G \\
\hline Keywords: \\
Blood transfusion; \\
Service System; \\
Good Manufacturing- \\
Practice;
\end{tabular}

Kata Kunci:

Sistem Pelayanan;

Transfusi Darah;

GMP; \begin{abstract}
A B S T R A C T
Good Manufacturing Practice (GMP) is an absolutely thing which has to do in every units of blood providers to eliminate the risks in the quality of Blood Providing Unit under the control of BPOM. The purposes of this research are; to get the information in budgeting aspect and government regulation; quality and personnel management; buildings, facilities and equipment; and the documentations of giving blood transfusion service according to GMP in UTD PMI of PM. The research method is qualitative based on the case study. UTD PMI of PM has not applied this as well as the others yet. Because of the government's regulation has not inclined yet. UTD PMI of PM is not consistent yet with GMP because of the low quality of the human resources. The buildings, facilities and equipment are not in compliance with GMP standard. The documentation is simple, it is incomplete and no commitment yet to make it runs. To overcome those obstacles, the comprehensive strategies are needed; such as government should publish the government regulation to support the blood services according to GMP and the commitment from the other parties to run it properly.
\end{abstract}

GMP merupakan hal yang mutlak dilaksanakan pada setiap unit penyedia darah untuk menghilangkan risiko terkait mutu dalam operasional UPD dengan pengawasan oleh BPOM. Tujuan penelitian untuk mengetahui aspek budgeting dan kebijakan pemerintah; manajemen mutu dan personalia; bangunan, fasilitas dan peralatan; serta dokumentasi dalam memberikan layanan darah menurut GMP di UTD PMI PM. Metode penelitian kualitatif dengan studi kasus. UTD PMI PM belum menerapkan dengan baik, karena belum berpihaknya kebijakan pemerintah. UTD PMI PM belum konsisten sesuai dengan GMP disebabkan kualitas sumber daya manusia belum memadai. Bangunan, fasiltas dan peralatan belum memenuhi standar GMP. Dokumentasi tergolong sederhana, belum lengkap dan belum ada komitmen dalam menjalankannya. Kendala tersebut memerlukan sebuah strategi secara komprehensif diantaranya kebijakan pemerintah berupa peraturan bupati harus diterbitkan segera yang mendukung layanan darah sesuai dengan GMP dan komitmen berbagai pihak untuk melaksanakan dengan baik.

(c) 2018 JMMR. All rights reserved

\section{INTRODUCTION}

Blood establishment should establish and maintain quality system, based on Good Manufacturing Practice (GMP) prinsiple involving all activities taht determine quality policy objectives and responsibilities, and should implement them by such means as quality planning, quality control, quality assurance and quality improvement. ${ }^{1}$

High standards of quality and safety of blood component have to be assured. These high standard can only be achieved by applying the principle od GMP during the collection, preparation, storage, dispatch, quality control and quality assurance. ${ }^{2}$

The system of GMP is a system of quality management in purpose to minimize the risks according to Blood Providing Unit (UPD), including the cross contamination, the contagion disease, or the unwanted ones, because of the using blood product. The effort is to increase the quality of blood in Indonesia done to fill the GMP by Indonesia National Agency of Drug and Food Control (BPOM). ${ }^{3}$

The legal basis of controlling the blood products by BPOM is the Medicare Legislation No 36/2009; the providence of donor and the processing of blood, are done by Blood Transfusion Unit (UTD) ${ }^{4}$; Government Regulation 7/2011 about blood services, the government has responsibility to manage, coach, and control the blood services; The Regulation of Health Minister 83/2014 about UTD, Hospital Blood Bank (BDRS) and blood transfusion service networks which BPOM as a part of assessment and licensed team of UTD member of transfusion service 
network, implementing external audit of UTD and BDRS, and authorized to do the external monitoring to UTD; the health ministry regulation about Plasma Fractionation which is UTD, centrals of Plasmapheresis the Plasma Fractionation industry has to fulfil the GMP and controlling by BPOM and the health ministry regulation 91/2015 about the standard of blood transfusion services that in order of controlling by BPOM, and authorize to administrative acts. The Regulation of Head of Indonesia National Agency of Drug and Food Control No 10/2017. The Regulation is about Guideline of Making Medicine Appropriately in Blood Transfusion Unit and Plasmapheresis Centre. ${ }^{1,2}$

UTD of Indonesia Red Cross (PMI) in PM is the first type and the only one UTD under the Indonesia Red Cross in West Sulawesi. The population of the West Sulawesi Regency is the most populous among all regencies in West Sulawesi, which are 427.484 lives from 1.282.160 lives of people in West Sulawesi.

UTD PMI of PM established since 2002, according to the classification is classify to the Regency UTD PMI and UTD PMI Pratama according to the services capability. In the attachment of the health ministry regulation number 84 , 2014, UTD PMI Pratama should have at least 1 head of the UTD, 1 medical staff, 4 technical executives, 2 administrations and finance executives, and 2 supporting officers. ${ }^{5,6}$ Those officers are expected to work as the fulltime officer. UTD PMI serves 24 hours a day with 3 shifts and it has 26 jobholders and 3contract employees.

Furthermore, UTD PMI also provides the mobile unit blood services twice a week to fulfil the needs of blood, which are getting increase. In 20131.979 blood bags are distributed, 2014 it reaches 2.662 blood bags, 2015 it reaches 3.146 blood bags, 2016 it reaches 4.527 blood bags, and 2017 almost 4.929 blood bags, pursue the target of WHO which is $2 \%$ from the population, which are \pm 8000 bags/year.

In the budgeting aspect, every years UTD gets the supporting finance from the government but it is not enough to fulfil the operational needs although the substitute cost have been given as it says in health ministry regulation and the Regent Decree of PM about Rp.360.000,- thus the equipment in UTD is still using the conventional check-up. Rapid Test method is still used as the preventive examination of transmitted infection through the blood transfusion (IMLTD). ${ }^{7}$ The building and the facilities built upon the government's ground thus it highly dependent on the government regulation. The quality and documentation management of blood services in UTD PMI PM also have not run well yet. Those indicators become the main reason of choosing the PM as the location of the research.

The UTD of PM are trying to apply the GMP, thus it needs an analyses related to the problems and the opportunity to applly the GMP in UTD PMI PM, with highlighting all of the aspect; 1) budgeting and government regulation, 2) quality and personnel management, 3) buildings, facilities, and equipment, 4) documentations. Those four aspects become the main focus of the research.

\section{RESEARCH METHOD}

This is a qualitative research with the case study. ${ }^{8,9}$ The subjects of the research are the parties that directly involved in the operational and blood services process in UTD PMI PM.

The object of the research are budgeting and government regulation; quality and personnel management; building, facilities and equipment; and documentation in UTD PMI PM.

The method of data processing is using the descriptive-analyses. The collected data consist of primer and seconder data. ${ }^{8,9}$ The primer datum collected from interview, observation, and Focus Group Discussion (FGD). Whereas the seconder data are collected from the study of the documents that had made by UTD PMI PM.

To select the respondents of blood services, the researcher proportional-sampling technique because of the limited time reason and the difficulty to adjust the meeting schedule, thus the researcher choose 20 persons in UTD PMI PM as the sample. The research takes place in UTD PMI PM, Jalan Ratulangi No. 52 PM, West Sulawesi. This research was conduct in June 2016 until November 2017.

\section{RESULT AND DISCUSSION}

The basic requirements of GMP are following:

a. All manufacturing processes are clearly defined by policies and standard operating prosedures (SOPs) are sistematically reviewed in the light of experience, and are shown to be capable of consistently manufacturing product of the required quality that comply with their specifications;.$^{10}$

b. Qualification of equipment and reagen dan validation of processes and methodes are performes prior to use in the manufacture of product intended for transfusion or further manufacturing;

c. All necessary resources are provide, including appropriately qualified and trained personnel, 
adequate permises, suitable equipment, apropriate materials, approved procedures and instruction, suitable storage and transport. ${ }^{10,11}$

d. A system is available to maintain traceability of all released product in order to facilitate recall, if necessary, of any product suspected of not conforming to standards and there is also a system to handle compliant; and

e. A system is available that addresses process and quality improvement function and activities. ${ }^{12,}$

\section{Budgeting and Government Regulation}

Budgeting is a systematically arranged plan covering all activities of the company, expressed in monetary units and applicable for certain periods of time in the future. Goverment policy is a decision made systematically by goverment with a spesific pupose and purpose that consern the public interest.

To support the operational of blood providing unit, a regulation about the Substitute Cost of Blood Processing (BPPD) has been made, which says that the maximum cost is Rp.360.000,-/ blood bag according to Letter of Health Minister No.HK/MENKES/31/1/2014 it also supported by the Letter of Decision by the Regent of PM No. KTSP/440/282/HUK 13 May 2014.

UTD PM has targeted to accomplish the GMP in 2023 but in the budgeting aspect, UTD has not stood independently yet, because of the blood production has not been enough yet to fulfil the minimum standard which is 1000 blood bags in a month or about Rp. 4.320.000.000,/year. At the moment the government only gives the support about 23,1\% (Rp.1.000.000.000,-/year). The income of UTD in 2017 is Rp.1.774.440.000,- UTD still lack the support about $35,8 \%$ (Rp.1.545.560.000,-) thus the UTD cannot give the maximal blood services yet but it has been done some internal decision according to the standard of GMP.

PM Hospital (RSUD) manages their finance with the system of Regional Public Service Agency (BLUD), has no Blood Bank (BDRS) yet, but it has finance plan to build the BDRS in 2018. Thus for the needs of blood transfusion, RSUD directly ask the UTD, has not done the blooddropping system yet, so the cross-macthing is still done by UTD. Then the RSUD has to give Rp.360.000,-/blood bag as the BPPD to the UTD.

The policy that has been issued by UTD PMI PM:

1. Repair and renovate the building where the service in accordance with the flow of service, so that donors dan family patients feel more comfortable.

2. Every action must be in accordance with SPOs and SPOs renewed every 2 years.

3. Multiply the mobile unit schedule from 2 times a week to at least 4 times a week.

4. Add vehiches for mobile units from 3 to 4 vehicles.

5. Cooperate with third parties for destruction of medical waste.

6. Effective personnel of mobile unit from 15 personnel to 5 personnel in 1 team.

7. Enganging in various goverment programs on malnutrition and maternal and child mortality.

8. Take an active role in national and religious holidays and other social activities.

9. Perform tool calibration in 2017.

10. Make policy of completion of blood request file from hospital/ clinic,

11. Blood-out of UTD is non-refundable.

12. On the organizational structure added independent quality managers.

13. Procerument of infection transmitted by blood transfusion examination 2018 with enzyme linked immunosorbent assay (ELISA) or Chemiluminescence immuno assay (CHLIA) method.

14. Procurement of blood donor management information system (SIMDONDAR) which has been operated on january 2018 .

\section{Quality Management and Personalia}

Quality management in UTD PMI PM, has not been run properly, but has strived implement quality management. Quality is the reponsibility of all persons involved in the various processes of the blood establishment. The management of the blood establishment is responsible for a systemic approach to quality and the implementation and maintenance of a quality management system. A quality programme should be desaigned to ensure that each product (including plasma for fractionation) is manufactured in the same manner from donor selection through to distribution of the final product (blood dan blood component).

The attainment of the quality policy and objectives is responsibilty of the Head of the blood establishment and requires the participation and commitment of all staff throuhgout the entire blood establishment should review the quality system at regular interval to verify its effectiveness 
and to introduce corrective measures if they are considered necessary. ${ }^{1,14}$

Within the organizational structure of the blood establishment there should be a quality management unit comprising one or more person. ${ }^{15}$ The quality management personnel should be responsible for ensuring that there is documented evidence that the quality policies, procedures and practices are being fullfilled. Head of the blood establishment, in coordination with the quality management unit, should develop and implement quality assurance policies and objectives in a manner that provides clear direction to all staff. ${ }^{1}$ The quality assurance policies and objectives should be desaigned to ensure the highest levels of safety and quality in the blood components that are procedures from each collection. The policies and procedures should comply with all national and, where appropriate, international regulations and requirement. ${ }^{1,14}$

Personnel should be able to understand the intent of the quality objectives and their own role in accomplishing the objectives. The performance of the quality management system should be evaluated periodically by determining whether the objectives have been or are continuously being met. If there are shortcoming in the quality system, corrections should be made and the quality management unit should be held responsible for monitoring corrective action and continued compliences. ${ }^{15,16}$

Blood establishments should ensure that blood components manufactured in their facilities are of the quality requeired for their intended use, comply with quality standard requirements, and do not place recipients at risk due to in adequate safety, quality or efficacy throughout the life-cycle of the product. In order to reliably achieve the quality objective, there should be a comprehensively designed and correctly implemented system of quality assurance that incorporates GMP and quality risk management (QRM). ${ }^{17}$

A formal change control system should be in place to plan, evaluate and document all changes that may affect the quality, traceability and availability of blood or blood component or that might have an impact on the safety of blood, blood component, donors and resipients. ${ }^{7,18}$

Any deviation from SOPs, validated processes, or non-conformances with specification or other quality related requirement should be recorder and investigated. The potensial impact on the quality of the product in question, or on other products, should be evaluated. ${ }^{7}$

Corrective action and preventive action (CAPA) system should be established, implemented, maintained to ensure that there is continous improvement at the blood establishment. The procedures should include the management of deviation and non-conformances, complaints, events and findings of the quality system management review, inspections and should ensure to proper recording of all CAPA taken. ${ }^{19}$

In order to monitor implementation and complience with the quality management system, regular internal inspections should be performed according to an established procedure. Internal inspection should be conducted by trained, independent and competent person under the responsibility of the quality assurance unit. ${ }^{14,15}$

All complaints, with the original details, should be recorded. Records should be retained of all the decisions, investigation and measures taken as a result of a complaint. Complaint record should be reviewed regularly in order to check for unfavourable trends or recurring problems and to ensure continous quality improvement. ${ }^{17}$

Recall operations should be initiated promptly and at any time. Therefore the SOPs should include emergency and out of hours contact details. Recall product should be destroyed. If recalled product are not destroyed, they should be clearly identified and stored separately in a secure area. ${ }^{7}$

Ideas for potensial improvement to any of the system may come from research, development, brainstrorming, or from of the management of non-conformances, event nd complaint, from internal or external inspection or inspection finding, and from deviations detected during quality monitoring activities. ${ }^{15}$

A written system should be in place for carrying out a look-back prosedure. This process should be able to trace the product collected from a donor to the final recipient and from the recipient back to the donor, preferably by means of a computer database. ${ }^{19}$

Personnel in UTD PMI PM increasing year by year. It is not only concentrated in the adding new personnel but also the focusing in increasing the quality human resources which available.

Table 1. Number of Staffs in UTD PMI PM

\begin{tabular}{lcc}
\multicolumn{1}{c}{ UTD Staffs } & UTD PMI PM & $\begin{array}{c}\text { Health Ministry } \\
\text { Regulation 83, } \\
\text { 2014 }\end{array}$ \\
\hline Head of UTD & 1 & 1 \\
Medical Staff & 1 & 1 \\
Technical Executive & 9 & 4 \\
Administration and & & \\
Finance Executives & 12 & 2 \\
Supporting Staff & 7 & 2 \\
\hline
\end{tabular}


The quality management in UTD PM has not run well yet because of every personnel has not understood their main task and functions yet. Besides the problems from the management aspects, the personnel system also become the main problem because it has found that some of personnel do the tasks, which are beyond their main task and functions.

Sufficient personnel should be available and should be given qualified to perform their tasks. They should have the appropriate qualifications and experience and should be given inisial and continuous training in order to assure the quality and safety of blood components.

Only persons who are competent in the manufacturing process and have read and understood all relevants SOPs should be involved in the manufacturing and distribution processes, including collections, quality control ann quality assurance. ${ }^{21}$

Task and responsibities should be clearly documented and understood. Personnel should be clear, current and written job descriptions. There should be an organizational chart showing the hierarchical structure of the blood establishment with clear delineation of lines of the responsibility and reporting.

Key personnel and their substitutes include the following functions:

a. Head of blood establishment is responsible for:

1. Ensuring that approved donor selection criteria are followed.

2. Ensuring that every unit of blood or blood component has been collected, tested, processed, stored, and distributions in compliance with the national regulations $i$ force.

3. Providing information to the competent national authority.

4. Ensuring that the required initial and on going training of personnel is carried out

5. Ensuring that a quality management syatem and haemovigilance system is in place in the blood establishment.

b. Head of blood processing or operations, responsible for all processing and operations activities.

c. Head of quality control, responsible for all quality control activities.

d. Head of quality assurance, reporting findings or quality issues directly to head of blood establishment and empowered to discontinue operations if quality and safety expectations are not being fulfilled.

e. Phycisians with the responsibility to ensure the safety of donors and the safety of the distributed blood components.

A variety of cases that often occur in UTD PMI PM, a staff cross job this is due to the lack of human resources in certain section so ask for help on other staff other than from his duty.

Sample case :

On certain days UTD PMI PM get donors in very large number, faced with situations like this, then the tasks of the logistics and delivering blood is usually handle by security guard. Simillary, the driver sometimes concurrently works other than as a driver. He also served as serving the donor and logistics arrangements. This is common because managemet is not well organized, on the other ghand the number staff is still lacking in sertain parts.

Personnel should receive initial and continuous training that is appropriate to their specific tasks. This training should be carried out by qualified trainers and should follow pre-arranged written programes. Training should be documented and training records should be retained. ${ }^{1,2}$

Approved training programmes should be in place and should also include:

a. Relevant principle of transfusion medicine.

b. GMP

c. Relevant knowledge in microbiology and hygiene.

The overall competency of personnel is a result of education, training and experience. As a key factor for the quality and safety of blood and blood product, competency has to be carefully evaluated and continuously monitored.

All personel, prior to being hired and during employment, as appropriate, should undergo health examinations. Any person shown at any time to have an illness or open lessions that may adversely affect the quality of the product and/or the safety of the donors should be excluded from establishment's manufacturing processes until the person's condition is no longer judged to be arisk. 2,22

To ensure protection of product, donors, and employes from contamination, personnel should wear clean protective clothing appropriate for the duties they perform. Soiled protective clothings, if reusable, should be stored in a separate closed container until properly laundered and, if necessary, desinfected or sterilized. Where appropriate, disposable or steril gloves should be worn when handling 
item that may come in contact with any blood or blood components. Personal hygiene procedures, including the use of appropriate protective clothing and equipment, should apply to all persons entering processing areas.

Table 2. Name of Personnel / Staff UTD PMI PM Following Human Resource Development

\begin{tabular}{|c|c|c|}
\hline N a m e & Position & Training \\
\hline \multirow[t]{3}{*}{ EP } & Head of UTD & Basic Blood Transfusion Doctor Training \\
\hline & & International Society Blood Transfusion \\
\hline & & Annual Scientific Meeting on Blood Transfusion \\
\hline \multirow[t]{5}{*}{ RA } & Head of Service & Technical training of blood transfusion unit \\
\hline & & Mobile operational training unit \\
\hline & & Refresher training of selection and engaging for UTD \\
\hline & & technicians \\
\hline & & The Quickwins Training of Blood Services \\
\hline \multirow[t]{3}{*}{$\mathrm{RR}$} & Aftaper & National Seminary of safe and quality blood services \\
\hline & & Technical capacity building exercises for UTD \\
\hline & & personnel \\
\hline \multirow[t]{2}{*}{$\mathrm{RD}$} & Head of Quality Control & Creatment Exercises Take Blood \\
\hline & & Safe and Rational Blood Transfusion rays \\
\hline $\mathrm{JD}$ & Laboratory & Basic Training of Serology Blood type \\
\hline UP & Laboratory & The National Seminar on Blood Services is safe and \\
\hline & & quality \\
\hline IA & Laboratory & Technical Capacity Building UTD officer \\
\hline MW & $\begin{array}{l}\text { Head of administration } \\
\text { division }\end{array}$ & Training Planning Monitor Evaluation Reporting \\
\hline $\mathrm{AM}$ & Adminitration & Training Planning Monitor Evaluation Reporting \\
\hline $\mathrm{AR}$ & Administration & A one-day seminar on the implementation of good drug \\
\hline & & manufacturing $(\mathrm{CPOB})$ in the field of blood services in \\
\hline & & Indonesia \\
\hline AW & Administration & Financial management \\
\hline AI & P2D2S & Donor Recruitment \\
\hline SU & Driver & Mobile unit operational training \\
\hline
\end{tabular}

\section{Building, Facilities and Equipment}

Building, facilities and equipment are the obstacles to fulfil the standard of GMP. The building of UTD PMI PM was built in 2002 and it has not been renovated yet except in 2016, it has been renovated in some of rooms. Even though it is not maximal yet of fulfilling the standard of GMP. UTD PMI PMis requiring building repair: medical examination room, donor recovery room,pantry, laboratory room (screening test, serology, component), blood storage space (blood storage and quarantine), waiting room of blood request, meeting room and supporting facilities that is motorcycle.

Design and construction of bulding, facilities and equipment:
1. Should be located, constructed, adapted and maintained to suit the operation that are to be carried out in them.

2. Should be desaign to permit effective cleaning and maintenance to minimize risk of contamination.

3. Lighting, temperature, humidity and ventilation should be appropriate and should not adversely affect processing or storage.

4. Should be desaigned and equipped so as to afford maximum protection againts the entry of animals, including insect.

5. Ancillary area should be separated from the donor evaluation area and from the screening, collection and manufacturing areas. 
6. Washing and toilet facilities, facilities for changing or eating should be maintained in a hygienic and tidy condition.

7. Each area of processing, testing and storage should be secured againts entry by unauthorized persons and should be used only for the intented purpose.

8. The donor area, blood processing and testing area should be separated from each other.

9. Should be maintenance and cleaned where appropriate disinfected according to SOPs. Cleaning records should be retained.

10. The area for blood donors should be separated from all processing and testing area.

11. The area for donor selection should permit confidental personal interview to take place.

12. Rest and refreshment rooms for donors should be separated from donation or storage areas.

13. Blood processing should be carried out in adequate facilities that are suitable for the purpose.

14. Whenever possible, closed systems should be used. Using a validated sterile connecting device create a functionally closed system.

15. When the use of a closed system is not possible or not appropriate, the risk of contamination or cross-contamination needs to be minimized. A less stringet environment may be acceptable if the preparation of the product is directly combined with additional safety measures, such as immediate transfusion within a defined and limited time period after processing or placing the product immediately into storage conditions that prohibit microbial growth.

16. Personnel performing open processing should wear apropriate clothing (suitable coats, masks or gloves) and should recieve regular training in aseptic manipulation.

17. Storage areas should provide adequate space and should be arranged in a way that allows for dry and onderly placement of stored materials.

18. Storage condition should be controlled, monitored and documented to show compliance with the specifications.

19. Temperature checks should be carried out and recorder at least daily.

20. Testing laboratories should be desaigned and constructed so as to minimize the risk or errors and contamination. Laboratory areas should be separated from the processing and final product storange area. ${ }^{1,2,6,22}$

The location of mobile unit is insufficient to do activities but it has provided appropriate scheme for the officers, donor, and product to minimize the risks of mistake. The activities of mobile unit is run as it planned which approved and fulfil the requirement but sometimes there are some problems such as a sudden invitation of blood donation so the location survey can't be done. As the result, it often finds the location of mobile unit that is not fulfil the standard requirement. The procedure has defined and explained in the Standard Operational Procedure of mobile unit and it has been documented but still not maximal yet. ${ }^{1,11}$

Mobile collection sites:

1. Premises for mobile collection sites should be adequate in design for the conduct of operation and should allow for the logical follow of staff, donors and product in order to minimize the risk of errors.

2. Ancillary areas (rest and refrehsment rooms) should be separated from donation or storage areas, but observatioan of donors during postdonation refreshment should still be ensured.

3. Before premises are accepted for mobile donors sessions their suitability should be assessed againts the following criteria:

a. Sufficient size to allow proper operation and ensure donor privacy.

b. Safety for donors and staff.

c. Ventilation, electrical supply, lighting, handwashing facilities, reliable communication, sufficient space for blood storage and transport, and suitable temperature conditions.

d. Each site should have an approved plan that details the site layout. The set-up of the mobile collection site should be carried out according to the approved plan. ${ }^{1,2,22}$

Equipment should be desaigned and installed to suit its intended purpose and should not present any hazart to donors, personnel and blood components and it should allow for effective cleaning, and disinfection is recommended for all surfaces in direct contact with the bag system.

Equipment should be located in a suitable position (e.g. balanced should be positioned on a suitable even 
surface) where there is no negative impact from the surrounding environmet (e.g. direct sunlight may have an impact on optical instrument sch as apheresis systems or balances). ${ }^{1,2,23}$

The quality of equipment currently available in UTD PMI PM is not sufficient to achieve GMP standard, as it still uses rapid test on infectious transmitted by blood tansfusion examination, which is not recommended by WHO because high risk of HIV/AIDS, hepatitis B, hepatitis $\mathrm{C}$ and syphilis. Examination for crossmatching test still uses a minimum standard/ convensional methods.

Maintenace, cleaning and calibration should be performed regularly and should be recorder. Maintenance of equipment should be carried out at intervals according to a documented schedule.

SOPs for use, maintenance, service, cleaning and sanitization should be available in a language that is understood by the user. There should be SOPs for each type of equipment, detailing the actions to be taken when malfunctions or failures occur. Defective equipment, or equipment that is not in service, should be clearly labelled and if possible removed from the working areas. ${ }^{7,17,19}$

Cleaning prosedure should be establish and describes in a SOP. Cleaning of equipment should take into consideration the instruction of the manufacturer. A schedule of regular cleaning and disinfection, if necessary, is recommended for all surface with direct contact with the bag system. ${ }^{2,10}$
Calibration should be carried out and documented recording to established SOPs and national regulations. Regular calibration is necessary for temperature probes, pipettes, balances, timing devices, haemoglobinometer devices. If the calibration consist of using a comparison measurement approach with a second device, than the maximum allowed deviation between the two measurement should be defined. 1,7,24

Critical compurized system should be validated before use. The system is considered critical if:

1. It is directly linked to the decision making process for blood product manufacturing, blood testing or blood product (donor/recipient), labelling and release.

2. It is used to handle or manipulate the related informations.

3. It has an impact on product quality, information management, storage, or tools, for operational decision making and control. ${ }^{1,25}$

\section{Documentation}

The documentation of procedures and records is essensial to the quality assurance system. It ensures that work is performed in a standardized and suniform manner and ensures the traceability off all steps. SOPs should includes all applicable methods and procedures and should be accessible to all authorized personnel. ${ }^{1,7}$

Table 3. List of Documents to be Prepared by UTD PMI PM for GMP standards

\begin{tabular}{|c|c|c|}
\hline No & Document & Findings \\
\hline 1 & Organizational structure & Available \\
\hline 2 & UTD establishment/operating license document & Not available \\
\hline 3 & UTD Map & Available \\
\hline 4 & Equipment list includes qualification/calibration status & Available \\
\hline 6 & Change control procedures & Not available \\
\hline 7 & Reporting procedures deviation/incident reporting quality system & Not available \\
\hline 8 & CAPA handling procedures & Not available \\
\hline 9 & Internal inspection procedures & Not available \\
\hline 10 & Grievance procedure or transfusion reaction report & Not available \\
\hline 11 & Product withdrawal procedure & Not available \\
\hline 12 & Look-back system procedure & Not available \\
\hline 13 & $\begin{array}{l}\text { Training procedures, personnel competencies, and job description of key } \\
\text { personnel }\end{array}$ & Available \\
\hline 14 & Document control procedures & Available \\
\hline 15 & The validation master plan (RIV) of 2018 & Not available \\
\hline 16 & A healthy blood smoothing procedure & Available \\
\hline 17 & Procedures for material and reagent smoothing include blood bags & Available \\
\hline 18 & Blood screening procedure for donor blood test & Available \\
\hline
\end{tabular}


Table 3.(Continued) List of Documents to be Prepared by UTD PMI PM for GMP standards

\begin{tabular}{llc}
\hline No & \multicolumn{1}{c}{ Document } & Findings \\
\hline 19 & Building maintenance procedures and equipment including computerized & Not available \\
& systems & Available \\
20 & Procedures for receiving and storing logistic goods & Not available \\
21 & Qualification centrifuge, blood bank, contact freezer shock, micropipet. & Available \\
22 & The protocol of the process of making blood components & Not available \\
23 & Validation of storage and delivery & Not available \\
24 & Reagent validation & Not available \\
25 & Calibration programs and procedures & Not available \\
26 & Procedure of backing up the computerized system & Available \\
27 & Reactive blood handling procedure & Available \\
27 & Crossmatch procedure & Available \\
29 & Mobile unit procedure & Not available \\
30 & Procedure pest control & Not available \\
31 & List of qualified suppliers &
\end{tabular}

The documentation from the procedure and files is very important in the quality control system. ${ }^{26}$ UTD PMI $\mathrm{PM}$ is currently trying to enforce computerized system although still using manual system also in searching all product since January 2018 and has made effort in enacting the computerized system to facilitate the search for SPO blood transfusion product and on process of giving blood services according to GMP. The blood services has been documented and it still too simple and not fulfil the standard of GMP yet because it still not complete yet and not done yet.

Activities should be carried out according to the SOPs. The processes and related SOPs should be regularly reviewed and updated as necessary in order to improve the quality of products and services delivered. The document review process should itself be documented. ${ }^{1,7,26}$

Each activity that may affect the quality of blood and blood component should be documented and recorded at the time it takes place. Critical activities should be doublechecked, either by a second person or electronically. There should be documentation to ensure that work is performed in a standardized manner according to SOPs and that all critical steps in the process are traceable especially those that have the potensial to affect the quality of the product. ${ }^{7}$ ${ }^{27}$ The documentation should allow all steps and all data to be confirmed by independent review. Documentation should indicate the person performing the action, the date of the action and the equipment used in the action, where applicable.

Document should be laid out in an orderly manner with a unique title and reference number, and should indicate the version and the effective date. The content of the document should be clear and should not include superfluous information. Title, nature, purpose and scope should be clearly outlined. Document should be reviewed, approved, signed and date by authorized persons. An audit trail should indicate the person responsible for each step of document control. ${ }^{1,2}$

Document management system should be in place. Document that outline spesific manufacturings step or other critical step should be readily available to the personnel performing these tasks. ${ }^{27} \mathrm{~A}$ document control SOP should be established for the development, review, approval, distribution, implementation, revision, and archival of document. When a document has been revised, the document management system should function in such a way as to prevent the inadvertent use of document that have been superseded. ${ }^{28}$

All record, including row data, which are critical to the safety and quality of blood or blood component should be kept in a secured storage area according to national regulation or preferably for at least 5 years. .,7

The part of GMP that is concerned with sampling, specification, and testing and that organization, documentation, and release procedures, which ensure that the necessary and relevant test are actually carried out and that materials are not released for use, nor products release for sale supply, until their quality has been judge to be satisfactory. ${ }^{29}$ Documentation is now being seen more as a system control, rather than just a record of batch production. It is suggested that a quality manual is procedure, recording and formal processes which control production. $^{7,29}$ 
Table 4. Blood Service Analysis

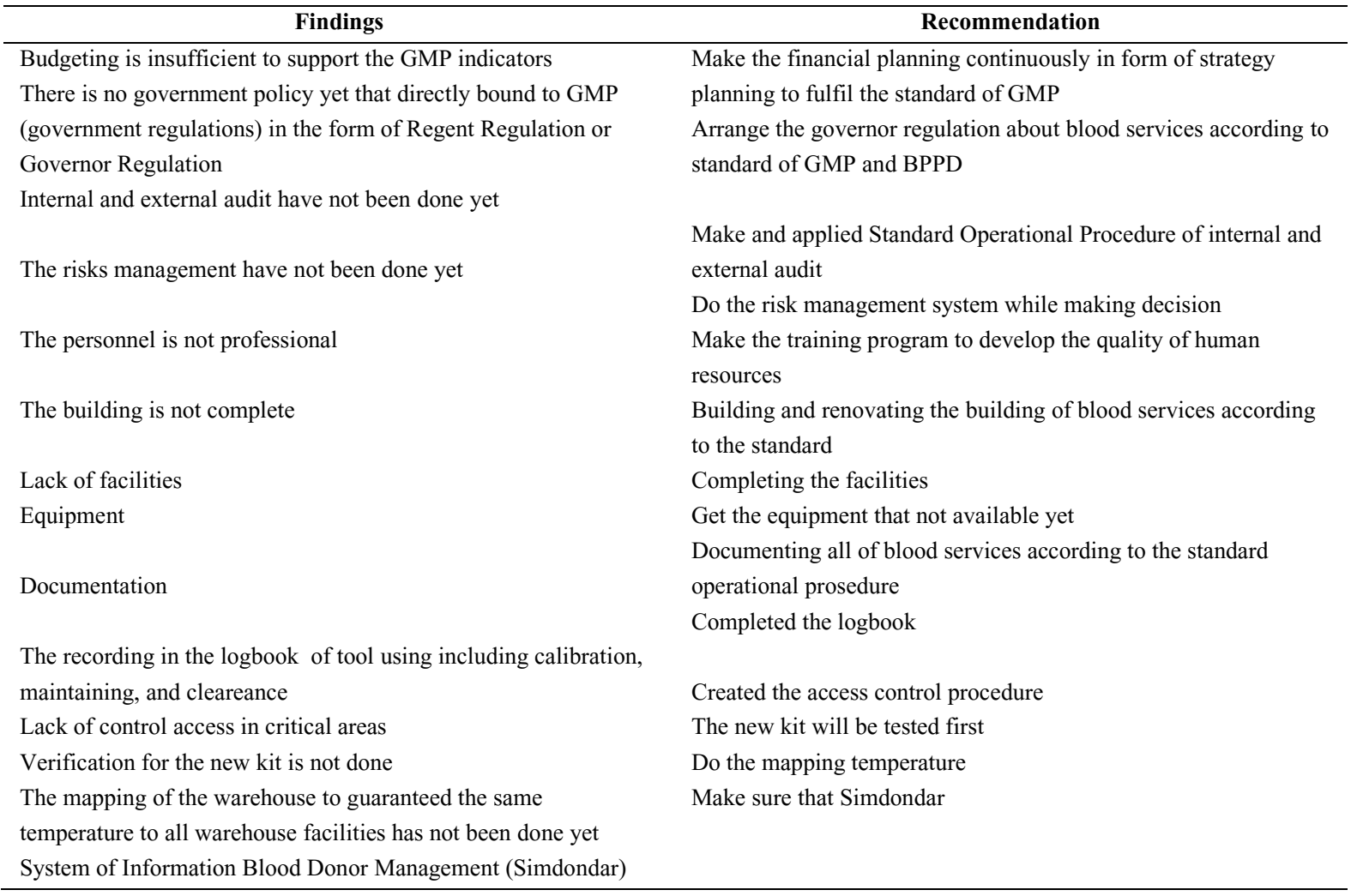

\section{CONCLUSION}

The system of blood services in UTD PMI PM do not fulfil the standard of GMP. The obstacles that found need the comprehensive strategy such as government regulation in regent policy, about supporting the blood services that fulfil the GMP requirement have to published as soon as possible and the commitment from the various parties to runs it appropriately.

\section{REFERENCE}

1. Peraturan Kepala Badan Pengawas Obat dan Makanan Republik Indonesia. 2017. Peraturan Pedoman Cara Pembuatan Obat yang Baik di Unit Transfusi Darah dan Pusat Plasmaferesis. Jakarta.

2. Badan Pengawas Obat dan Makanan Republik Indonesia. 2016. Draft Pedoman CPOB Untuk Unit Penyedia Darah. BPOM RI. Jakarta.

3. Laksono, A. D., Humaniora, P., Kesehatan, K., \& RI, K. K. 2013. Keamanan Darah di Indonesia.

4. Darmawan, A., \& Irawan, R. 2015. Mengenal CPOB Untuk Produk Darah. Jambi Medical Journal, 3(2).
5. Kementerian Kesehatan Republik Indonesia. 2014. Unit Transfusi Darah, Bank Darah Rumah Sakit, dan Jejaring Pelayanan Transfusi Darah. Jakarta.

6. Kementerian Menteri Kesehatan Republik Indonesia. 2015. Standar Pelayanan Transfusi Darah. Jakarta.

7. World Health Organization. 2017. Strategic framework for blood safety and availability 20162025.

8. Jonker. J, Pennik. J.W, Wahyuni, S, 2011, Metodologi penelitian: Panduan untuk master dan Ph.D. di bidang Manajemen. Salemba Empat. Jakarta.

9. Herdiansyah. H, 2012, Metodologi Penelitian Kualitatif: Untuk ilmu-ilmu sosial. Salemba Humanika. Jakarta.

10. Kementerian Menteri Kesehatan Republik Indonesia. 2015. Petunjuk Teknis Pelaksanaan Program Kerjasama Puskesmas, UTD dan RS dalam Pelayanan Darah untuk menurunkan AKI. Jakarta.

11. Jovanović, R., RadlovaČki, V., PeČujlija, M., Kamberović, B., Delić, M., \& Grujić, J. 2012. Assessment of blood donors' satisfaction and measures to be taken to improve quality in transfusion service establishments. Medicinski glasnik (BiH), 9(2), 231-238 
12. Custer, B., Janssen, M. P., \& Alliance of Blood Operators Risk-Based Decision-Making (RBDM) Initiative. 2015. Health economics and outcomes methods in risk-based decision-making for blood safety. Transfusion, 55(8), 2039-2047.

13. Sari, E. N. 2016. Konsep Anggaran dalam Perspektif Balance Scorecard: Suatu Tinjauan Teoritis. Jurnal Riset Akuntansi \& Bisnis.

14. Seifried, E., Klueter, H., Weidmann, C., Staudenmaier, T., Schrezenmeier, H., Henschler, R., \& Mueller, M. M. 2011. How much blood is needed? Vox sanguinis, 100(1), 10-21.

15. Darbandi, A., Mashati, P., Yami, A., Gharehbaghian, A., Namini, M. T., \& Gharehbaghian, A. 2017. Status of blood transfusion in World Health OrganizationEastern Mediterranean Region (WHO-EMR): Successes and challenges. Transfusion and Apheresis Science, 56(3), 448-453.

16. Region, E. M. 2016. Local Day Donors and Donation. Strategies, 1, 01-02.

17. Kubio, C., Tierney, G., Quaye, T., Nabilisi, J. W., Ziemah, C., Zagbeeb, S. M., \& Murphy, W. G. 2012. Blood transfusion practice in a rural hospital in Northern Ghana, Damongo, West Gonja District. Transfusion, 52(10), 2161-2166.

18. Murphy, W. G., Katz, L. M., \& Flanagan, P. 2013. Regulatory aspects of blood transfusion. Practical Transfusion Medicine, Fourth Edition, 169-180.

19. Goldman, M. 2013. Donor selection for recipient safety. ISBT Science Series, 8(1), 54-57.

20. Milkins, C., Berryman, J., Cantwell, C., Elliott, C., Haggas, R., Jones, J., \& Win, N. 2013. Guidelines for pre-transfusion compatibility procedures in blood transfusion laboratories. Transfusion Medicine, 23(1), 3-35.

21. Strengers, P. 2011. Key elements of a blood transfusion quality management system, the tools and objectives. ISBT Science Series, 6(1), 21-25.

22. White, S., Pearson, J., Lofthouse, J., \& Knighton, C. 2013. Blood Donation: Recruiting Donor Carers Who Can Care For Blood Donors. Vox Sanguinis, 105(1), 65-299.

23. Vuk, T., Barišić, M., OČić, T., Mihaljević, I., Šarlija, D., \& JukiĆ, I. 2012. Error management in blood establishments: results of eight years of experience (2003-2010) at the Croatian Institute of Transfusion Medicine. Blood Transfusion, 10(3), 311.

24. Yasmin, A. 2011. Plasma Fractionation in Malaysia. Iranian Journal of Blood and Cancer, 3(3), 107-110.

25. Lam, S. 2011. Quality systems management and overview Quality Management, 20 November 2011. ISBT Science Series, 6(2), 277-279.

26. Ceulemans, J., Compernolle, V., Vantyghem, W., \& Vandekerckhove, P. 2013. Self-inspection of blood establishments. ISBT Science Series, 8(1), 28-32

27. Bust, L. 2013. Importance of documentation in GMP. ISBT Science Series, 8(1), 16-18.

28. Paul, C., Moore, A., Dickson, N., Storey, G., Peters, J., Ritchie, S., \& McDonald, G. 2014. Report to the Blood Service: Behavioural Donor Deferral Criteria Review.

29. Slopecki, A., Smith, K., \& Moore, S. 2007. The value of good manufacturing practice to a blood service in managing the delivery of quality. Vox sanguinis, 92(3), 187-196. 